\title{
WNIOSEK BENEFICJENTA O PŁATNOŚĆ JAKO NARZĘDZIE MONITOROWANIA PRAWIDŁOWOŚCI REALIZACJI PROJEKTU WSPÓŁFINANSOWANEGO Z FUNDUSZY UNIJNYCH
}

Z a r y s t r e ś c i: Celem artykułu jest prezentacja wniosku beneficjenta o płatność jako instrumentu monitorowania zgodność realizacji projektu z wnioskiem aplikacyjnym, umową o dofinansowanie, założeniami programu operacyjnego oraz prawem krajowym i wspólnotowym. Dla zrealizowania powyższego celu w publikacji przedstawiono charakterystykę systemu sprawozdawczości i monitorowania programów operacyjnych oraz obowiązujące w perspektywie finansowej 2007-2013 narzędzia sprawozdawcze. Artykuł prezentuje wyniki badania jakościowego przeprowadzonego $\mathrm{z}$ przedstawicielami instytucji wdrażających PO IG, zaangażowanych w proces weryfikacji wniosków o płatność. Przeprowadzone wywiady umożliwiły ocenę roli sprawozdań z realizacji projektów w procesie wdrażania programów operacyjnych oraz zidentyfikowanie uchybień i nieprawidłowości najczęściej wykrywanych w procesie weryfikacji wniosków o płatność.

S ło w a k l u c z o w e: wniosek beneficjenta o płatność, fundusze unijne

K 1 a s y fik a c j J E L: L 21

\section{WSTĘP}

Priorytetem polityki spójności Unii Europejskiej jest wydatkowanie funduszy wspólnotowych $\mathrm{w}$ sposób zapewniający trwałe pozytywne zmiany w regionach objętych pomocą. Efektywne wydatkowanie środków budżetu ogólnego przez beneficjentów ma zapewnić zrównoważony wzrost, którego

\footnotetext{
* Adres do korespondencji: Aneta Żbik, Politechnika Częstochowska Wydział Zarządzania, Instytut Finansów, Bankowości i Rachunkowości, al. Armii Krajowej 19, Częstochowa, e-mail: aneta. zbik@interia.eu;
} 
kluczowymi miernikami są wzrost zatrudnienia oraz podniesienie konkurencyjności regionów. Priorytety przyświecające realizacji polityki spójności przekładają się bezpośrednio na obowiązki nakładane na beneficjentów korzystających z pomocy finansowej Unii Europejskiej, zarówno w trakcie realizacji projektów, jak i po ich zakończeniu.

Dokumentem regulującym prawa i obowiązki beneficjentów pomocy unijnej jest umowa o dofinansowanie. Przedmiotowa umowa zobowiązuje biorców pomocy do realizacji wszystkich działań zaplanowanych w harmonogramie rzeczowo-finansowym, osiągnięcia założonych we wniosku aplikacyjnym wskaźników produktu i rezultatu, przestrzegania regulacji obowiązujących w danym programie operacyjnym, respektowania prawa krajowego i wspólnotowego oraz zasad i polityk Unii Europejskiej, informowania opinii publicznej o źródłach finansowania realizowanych przedsięwzięć oraz utrzymania trwałości projektów. Wywiązywanie się beneficjentów z obowiązków nałożonych na podstawie umowy o dofinansowanie jest nadzorowane przez instytucje udzielające wsparcia. Podstawowym narzędziem monitorowania prawidłowości realizacji zawartej umowy o dofinansowanie $\mathrm{w}$ trakcie realizacji projektu jest wniosek o płatność. Wywiązywanie się beneficjentów z obowiązku terminowego przekazywania rzetelnie sporządzonych jest jednym z kluczowych warunków skutecznego zarządzanie programem operacyjnym. Informacje o charakterze finansowym i rzeczowym dostarczane przez beneficjentów wykorzystywane są do monitorowania prawidłowości realizacji projektu zarówno w ujęciu rzeczowym jak i finansowym. Dostarczane przez beneficjentów dane stanowią podstawę do sporządzenia przez instytucje zaangażowane we wdrażanie programów operacyjnych informacji kwartalnych oraz sprawozdań okresowych, rocznych i końcowych przekazywanych do Instytucji Koordynującej Narodowe Strategiczne Ramy Odniesienia (IK NSRO) oraz Komisji Europejskiej (KE).

Informacje zaprezentowane $\mathrm{w}$ artykule są rezultatem analizy danych zastanych, badań własnych autora oraz doświadczenia zawodowego zdobytego w trakcie pracy w obszarze wdrażania Regionalnego Programu Operacyjnego Województwa Łódzkiego na lata 2007-2013 (RPO WŁ) oraz Programu Operacyjnego Innowacyjna Gospodarka (PO IG). Dane wtórne przedstawione w artykule zostały zaczerpnięte $\mathrm{z}$ literatury przedmiotu, wytycznych regulujących zasady wdrażania funduszy unijnych w perspektywie finansowej 2007-2013 oraz publikacji instytucji zaangażowanych we wdrażanie programów operacyjnych.

Na potrzeby artykułu w marcu 2017 r. przeprowadzono 7 indywidualnych wywiadów pogłębionych (IDI) z pracownikami instytucji, zaangażowanych we wdrażanie PO IG, posiadających doświadczenie zawodowe w obszarze weryfikacji wniosków o płatność w tym: 4 wywiady z pracownikami Departamentu Programów Wsparcia Innowacji i Rozwoju Ministerstwa Rozwoju (IZ PO IG), 1 wywiad z pracownikiem Polskiej Agencji Rozwoju Przedsiębiorczości 
(IW PO IG), 1 wywiad z pracownikiem Banku Gospodarstwa Krajowego (IW PO IG) oraz 1 wywiad z pracownikiem Narodowego Centrum Badań i Rozwoju (IP PO IG) ${ }^{1}$.

\section{ZAŁOŻENIA SYSTEMU SPRAWOZDAWCZOŚCI I MONITORINGU W PERSPEKTYWIE FINANSOWEJ 2007-2013}

Ramy systemu sprawozdawczości dla programów operacyjnych realizowanego w ramach Narodowych Strategicznych Ram Odniesienia (NSRO) zdefiniowane zostały w Wytycznych Ministra Rozwoju w zakresie sprawozdawczości, wydanych na podstawie art. 35 ust. 3 pkt 6 ustawy z 6 grudnia 2006 r. o zasadach prowadzenia polityki rozwoju [Dz. U. z 2014 r. poz. 1649 , ze zm.].

Przedmiotowe wytyczne definiują sprawozdawczość jako system zbierania informacji dotyczących realizacji poszczególnych programów z uwzględnieniem działań/grup operacji, osi priorytetowych w postaci danych liczbowych, finansowych, w tym wskaźników rzeczowych i finansowych i innego rodzaju informacji oraz przekazywanie ich odpowiednim instytucjom w określonym trybie, formie, zakresie i terminach, dla potrzeb monitorowania realizacji programu operacyjnego na każdym poziomie jego wdrażania [Ministerstwo Rozwoju, 2016, s. 4]. Celem realizacji procesu monitorowania programu operacyjnego jest zapewnienie realizacji celów strategicznych i operacyjnych określonych w programie oraz pełnej absorpcji przyznanych przez Komisję Europejską środków. Monitorowanie finansowe jest podstawą oceny sprawności wydatkowania środków z funduszy europejskich. Monitorowanie rzeczowe to nadzorowanie postępu realizacji programów i projektów przez system wskaźników określonych w dokumentach programowych [Trocki M., Grucza B., 2007, s. 225-226].

Prawidłowy i efektywny monitoring programu operacyjnego zapewnia podmiotom wdrażającym ${ }^{2}$ dostęp do danych będących podstawą oceny skuteczności realizacji celów programu w ujęciu rzeczowym i finansowym a także wczesną identyfikację problemów i możliwość podjęcie niezbędnych działań zaradczych.

Wytyczne, adresowane do instytucji zarządzających krajowymi i regionalnymi programami operacyjnymi, określają tryb, formy, zakres i terminy sprawozdawczości oraz wzory narzędzi sprawozdawczych tj.: wniosku o płatność, informacji kwartalnej oraz sprawozdania okresowego,

\footnotetext{
${ }^{1}$ Pracownicy PARP, BGK i NCBR uczestniczący w wywiadach odpowiedzialni są za sporządzanie raportów o nieprawidłowościach podlegających raportowaniu do KE oraz zestawień o nieprawidłowościach niepodlegających raportowaniu wykrytych w ramach POIG
}

${ }^{2}$ Instytucjom zarządzającym (IZ), Pośredniczącym (IP) oraz Wdrażającym (IW) 
rocznego i końcowego. Pierwsze z narzędzi tj.: wniosek o płatność jest składane przez każdego z beneficjentów programu operacyjnego i stanowi sprawozdanie zrzeczowej i finansowej realizacji projektu. Pozostałe dwa narzędzia sprawozdawcze tj. informacja kwartalna i sprawozdania (okresowe, roczne i końcowe) adresowane są do instytucji zarządzających programami operacyjnymi. Sprawozdania z realizacji programu oraz informacje kwartalne przedkładane były w perspektywie finansowej 2007-2013 do Instytucji Koordynującej Narodowe Strategiczne Ramy Odniesienia (IK NSRO) oraz do wiadomości Instytucji Certyfikującej (IC) i InstytucjiZarządzającejProgramem OperacyjnymPomoc Techniczna(IZPOPT). Dla minionego okresu programowania funkcję IK NSRO pełni Departament Koordynacji Wdrażania Funduszy Unii Europejskiej Ministerstwa Rozwoju. Funkcję IC sprawuje Departament Certyfikacji i Desygnacji Ministerstwa Rozwoju. Podstawą do sporządzenia informacje kwartalnych oraz sprawozdań były dane wygenerowane $\mathrm{z}$ wdrożonego na potrzeby realizacji polityki spójności w Polsce systemu KSI SIMIK 07-133. Dane w systemie informatycznym rejestrowane są przez wszystkie instytucje zaangażowane we wdrażanie programów operacyjnych. KSI SIMIK 07-13 zawiera informacje dotyczące realizacji każdego programu operacyjnego w tym m.in.: dane o naborach wniosków aplikacyjnych, dane o zawartych umowach o dofinansowanie/wydanych decyzji, dane o wypłaconych zaliczkach oraz złożonych wnioskach o płatność, informacje o przeprowadzonych kontroli (na miejscu, trwałości projektów, na dokumentach, krzyżowych programu operacyjnego i horyzontalnych) oraz zarejestrowane obciążenia na projektach (wynikające $\mathrm{z}$ wydanych przez instytucje systemu wdrażania decyzji o zwrocie środków).

Sprawozdania $\mathrm{z}$ realizacji programu operacyjnego, sporządzane m.in. w oparciu o dane wygenerowane z KSI SIMIK 07-13, przedkładane są do Komisji Europejskiej, która w oparciu o uzyskane dane dokonuje oceny skuteczności interwencji funduszy strukturalnych, co w konsekwencji przekłada się na przyszły kształt polityki spójności [Piątkowska K., Wielguszewska K., 2008, s. 34]. Powyższe świadczy o olbrzymiej roli procesu pozyskiwani informacji o stanie wdrażania projektów współfinansowanych ze środków unijnych oraz efektach (rezultatach) ich realizacji.

\section{OBOWIĄZKI SPRAWOZDAWCZE BENEFICJENTÓW REALIZUJĄCYCH PROJEKTY UNIJNE}

Głównym źródłem pozyskiwania przez instytucje zarządzające programami operacyjnym informacji o postępach $\mathrm{w}$ realizacji wybranych do dofinansowania projektów jest składany cyklicznie wniosek beneficjenta o płatność.

\footnotetext{
${ }^{3}$ w oparciu o Oracle Business Intelligence
} 
W perspektywie finansowej 2007-2013, w porównaniu do okresu programowania 2004-2006, ograniczono obowiązki sprawozdawcze na poziomie beneficjenta łącząc funkcję wnioskowania o płatność ze sprawozdaniem z realizacji projektu [Ministerstwo Rozwoju, 2016, s.4]. Dzięki wdrożonemu uproszczeniu realizator projektu składa do właściwej instytucji nadzorującej przebieg przedsięwzięcia tylko wniosek o płatność. W analizowanym okresie programowania proces przekazywania publicznych środków krajowych (wkład budżetu państwa) i wspólnotowych (wkład Unii Europejskiej) został oparty na analizie postępu rzeczowego projektu weryfikowanego $\mathrm{w}$ oparciu o harmonogram rzeczowo finansowy, stanowiący załącznik do umowy o dofinansowanie.

Zgodnie z pkt 6.4 Wytycznych w zakresie sprawozdawczości pozytywnie i w całości zweryfikowana część wniosku beneficjenta o płatność dotycząca przebiegu realizacji projektu, wskazująca na właściwą realizację przedsięwzięcia jest warunkiem koniecznym zrealizowania płatności na rzecz realizatora projektu. Obowiązek beneficjenta $w$ zakresie składania sprawozdań oraz konsekwencje wynikające $\mathrm{z}$ nieprawidłowej lub nieterminowej sprawozdawczości określa umowa/decyzja o dofinansowanie. Częstotliwość składania oraz zakres informacyjny (tzw. minimalne wymogi) wniosku o płatność określają Wytyczne w zakresie sprawozdawczości. Zgodnie z pkt 6.5 Wytycznych wniosek beneficjenta o płatność powinien być składany co najmniej raz na trzy miesiące. Bieg przedmiotowego terminu liczony jest od momentu podpisania umowy/wydania decyzji o dofinansowanie.

Przyjmując za kryterium podziału cel złożenia sprawozdania z realizacji projektu możemy wyodrębnić pięć typów wniosków o płatność:

- Wniosek sprawozdawczy - składany jest w sytuacji, w której beneficjent nie poniósł wydatków w okresie sprawozdawczym. Dokument służy przekazaniu informacji o postępie rzeczowym projekt,

- Wniosek o płatność zaliczkowa - składany jest w celu wypłaty zaliczki dofinansowania na realizację projektu. Warunkiem wypłaty środków jest ujęcie płatności zaliczkowej $\mathrm{w}$ harmonogramie płatności stanowiącym załącznik do umowy o dofinansowanie,

- Wniosek rozliczający zaliczkę - składany jest przez beneficjenta w celu rozliczenia wypłaconej zaliczki. Dokument może również stanowić podstawę do wypłaty kolejnej transzy dofinansowania pod warunkiem rozliczenia w złożonym dokumencie dotychczas otrzymanych zaliczek w wysokości wskazanej w umowie (70-100 proc.),

- Wniosek o przekazanie płatności pośredniej - składany jest przez beneficjenta, który w okresie sprawozdawczym sfinansował poniesione wydatki kwalifikowalne środkami własnymi. Wniosek stanowi podstawę do wypłaty refundacji, 
- Wniosek o przekazanie płatności końcowej - składany jest przez beneficjenta $\mathrm{w}$ związku z zakończeniem realizacji projektu (w zależności od zapisów umowy o dofinansowanie w ostatnim dniu realizacji projektu lub w ciągu 30 dni od jego zakończenia). Wniosek stanowi podstawę do wypłaty na rzecz beneficjenta ostatniej płatności. Wypłata dofinansowania często wstrzymywana jest do czasu przeprowadzenia kontroli na zakończenie realizacji projektu ${ }^{4}$.

Warunkiem wypłaty dofinansowanie jest złożenie poprawnego i kompletnego wniosku o płatność wraz z niezbędnymi załącznikami. W zależności od programu operacyjnego i instytucji nadzorującej realizację danego poddziałania/działania mogą istnieć odrębne wymogi w zakresie formy sporządzenia wniosku o płatność. Dokument może być sporządzany $\mathrm{w}$ generatorze wniosków lub na elektronicznym formularz (w programie Microsoft Word) opracowanym przez IZ/IP/IW. Niezależnie od narzędzia, w którym sporządzany jest wniosek dokument musi zostać wydrukowany i podpisany przez osobę upoważnioną do reprezentowania beneficjenta oraz złożony w formie papierowej i elektronicznej.

Zestawienie najczęściej wymaganych załączników składanych przez beneficjentów w ramach obowiązku sprawozdawczego przedstawia tabela nr 1 .

W ramach każdego wniosku o płatność beneficjent składa oświadczenia dotyczące niepodlegania wykluczeniu z możliwości otrzymania dofinansowania, braku podwójnego finansowania, kwalifikowalności/niekwalifikowalności podatku VAT, prowadzenia wyodrębnionej ewidencji księgowej na potrzeby realizacji projektu oraz o zgodności z prawdą informacji zawartych we wniosku o płatność. Oświadczenia składane są pod rygorem odpowiedzialności karnej, wynikającej z art. 297 kodeksu karnego.

Złożony wniosek o płatność podlega ocenie formalnej oraz merytorycznej i finansowej. Zatwierdzony dokument stanowi podstawę do wypłaty, wynikającego z harmonogramu płatności, dofinansowania. W przypadku negatywnego wyniku weryfikacji wniosku o płatność beneficjent wzywany jest do złożenia korekty dokumentu. W sytuacji uchylania się od wprowadzenia poprawek wskazanych w wezwaniu wniosek o płatność może podlegać odrzuceniu.

\footnotetext{
${ }^{4} \mathrm{~W}$ przypadku podjęcia przez instytucję będącą stroną umowy o dofinansowanie decyzji o przeprowadzeniu kontroli w miejscu realizacji projektu.
} 
Tabela nr 1. Zestawienie załączników składanych wraz z wnioskiem o płatność przez beneficjentów programów operacyjnych.

\begin{tabular}{|c|c|}
\hline $\begin{array}{c}\text { Rodzaj } \\
\text { wniosku o } \\
\text { płatność }\end{array}$ & Załączniki składane wraz z wnioskiem beneficjenta o płatność ${ }^{5}$ \\
\hline $\begin{array}{l}\text { Wniosek } \\
\text { sprawoz- } \\
\text { dawczy lub } \\
\text { o płatność } \\
\text { zaliczkową }\end{array}$ & $\begin{array}{l}\text { - Harmonogram płatności, } \\
\text { - Inne dokumenty niezbędne do zweryfikowania informacji zawartych } \\
\text { we wniosku/dokumenty nie dostarczone na etapie podpisania umowy } \\
\text { o dofinansowanie np.: Zaświadczenie o statusie podatnika podatku VAT', Ocena oddzia- } \\
\text { tywania przedsięwzięcia na środowisko, pozwolenie na budowę. }\end{array}$ \\
\hline $\begin{array}{l}\text { Wniosek } \\
\text { rozli- } \\
\text { czajacy } \\
\text { zaliczke, } \\
\text { o płatność } \\
\text { pośrednia } \\
\text { lub } \\
\text { o płatność } \\
\text { końcowa }\end{array}$ & 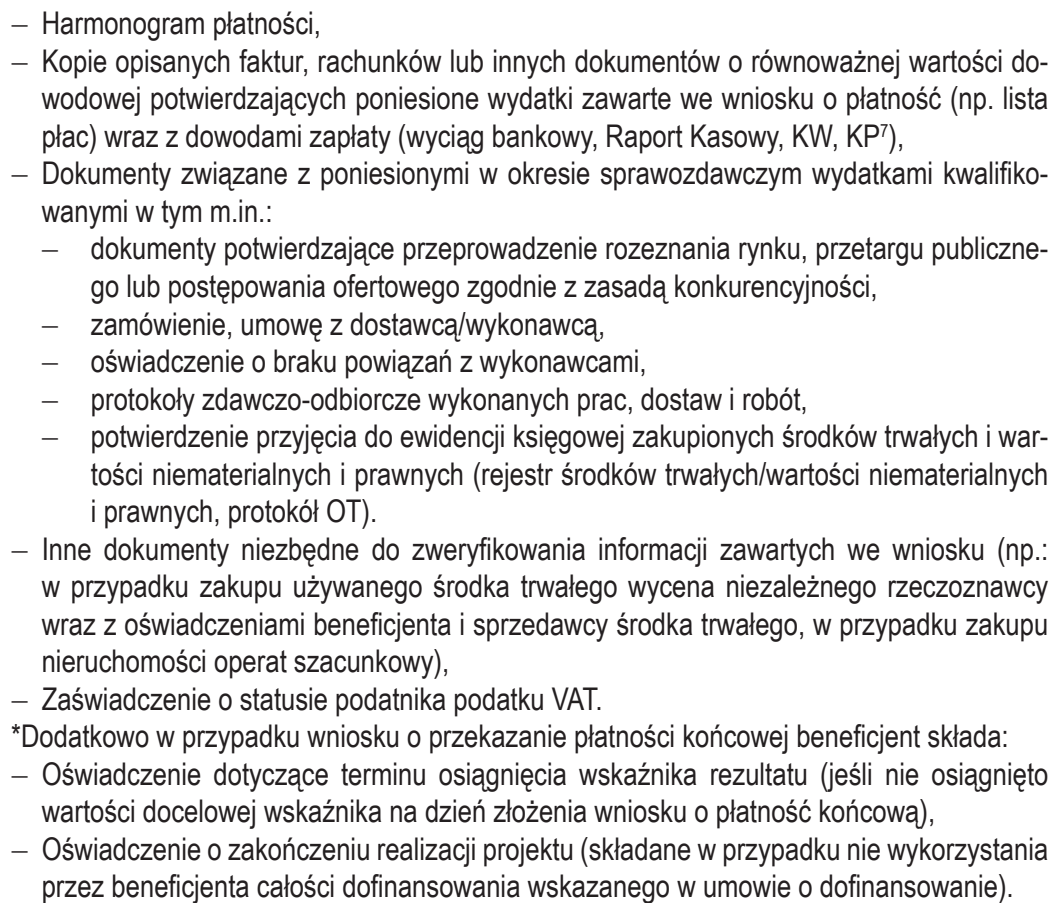 \\
\hline
\end{tabular}

Źródło: Opracowanie własne na podstawie: materiałów szkoleniowych PARP Zasady sporządzania wniosku beneficjenta o płatność: https://poig.parp.gov.pl/files/74/108/204/18223.pdf [02.04.2017], Instrukcji wypełniania wniosku beneficjenta o płatność w ramach RPO WŁ na lata 2007-2013, III oś priorytetowa Gospodarka, Innowacyjność, Przedsiębiorczość :http://www.20072013.cop. lodzkie.pl/index.php/component/content/article/227.html\#zalaczniki_do_wniosku_o_platnosc [04.02.2017].

\footnotetext{
${ }^{5}$ Wszystkie kopie dokumentów składanych wraz z wnioskiem o płatność musza być potwierdzone za zgodność z oryginałem przez osobę upoważnioną do reprezentowania beneficjenta.

${ }^{6}$ Zaświadczenie składane jest raz w roku kalendarzowym przez cały okres realizacji projektu. Dokument potwierdzenia statusu podatnika podatku VAT.
}

${ }^{7}$ Jeśli właściwa instytucja dopuszcza dokonywanie płatności gotówkowych w ramach projektu. 
Proces weryfikacji wniosku o płatność przeprowadzany jest w oparciu o zasadę „dwóch par oczu” w poniższych etapach:

- I etap - ocena formalna obejmująca weryfikację prawidłowości formularza na którym został złożony wniosek (w tym kompletności wypełnienia pól), terminowości złożenia dokumentu, poprawności złożonych na wniosku podpisów, tożsamości wersji papierowej i elektronicznej dokumentu oraz kompletności dołączonych załączników,

- II etap - weryfikacja merytoryczna i finansowa obejmuje m.in.: ocenę kwalifikowalności wydatków ${ }^{8}$, weryfikację adekwatności stopnia realizacji wskaźników produktu i rezultatu w stosunku do rzeczowego postępu realizacji projektu, ocenę prawidłowość rozliczeń finansowych oraz sprawdzenie możliwość wystąpienia podwójnego finansowania tych samych wydatków.

Proces oceny wniosku o płatność umożliwia instytucji udzielającej wsparcia wykrycie uchybień i nieprawidłowości w realizacji projektu. W zależności od funkcji wniosku o płatność (wniosek rozliczający zaliczkę lub wniosek o płatność pośrednią/końcową) wykrycie nieprawidłowości może nastąpić przed lub po dokonaniu płatności na rzecz beneficjenta.

\section{NIEPRAWIDŁOWOŚCI WYKRYWANE W PROCESIE WERYFIKACJI WNIOSKÓW O PŁATNOŚĆ NA PRZYKŁADZIE PO IG 2007-2013}

Kluczową kwestią poruszoną w trakcie wywiadów z przedstawicielami instytucji zaangażowanych we wdrażanie PO IG 2007-2013 było zidentyfikowanie typów nieprawidłowości ${ }^{9}$, wykrywanych w trakcie weryfikacji wniosków o płatność.

W wyniku przeprowadzonych wywiadów ustalono, że proces oceny wniosków o płatność (obok kontroli projektów na miejscu realizacji) jest podstawowym źródłem informacji o postępach rzeczowo-finansowych współfinansowanych przedsięwzięć. Weryfikacja sprawozdań beneficjentów umożliwia zarówno bieżący monitoring działań projektowych jak i wykrycie nieprawidłowości/

\footnotetext{
${ }^{8} \mathrm{~W}$ ramach weryfikacji kwalifikowalności wydatków ocenie podlega: termin i prawidłowość poniesienia wydatków, niezbędność wydatków do realizacji projektu, zgodność wydatków z programem operacyjnym (działaniem/poddziałaniem) oraz z umową i wnioskiem o dofinansowanie, przestrzeganie zasady konkurencyjności/PZP, zgodność realizacji projektu z politykami wspólnotowym oraz prawem krajowym i unijnym.

${ }^{9}$ Zgodnie z art. 2 pkt 7 Rozporządzeniem Rady (WE) 1083/2006 z dnia 11 lipca 2006 r. za nieprawidłowość należy uważać jakiekolwiek naruszenie przepisu prawa wspólnotowego wynikające z działania lub zaniechania podmiotu gospodarczego, które powoduje lub mogłoby spowodować szkodę w budżecie ogólnym Unii Europejskiej w drodze finansowania nieuzasadnionego wydatku z budżetu ogólnego. Konsekwencją wystąpienia nieprawidłowości jest uznanie wydatku poniesionego w ramach projektu za niekwalifikowany (w całości lub części).
} 
uchybień [Domiter M., Marciszewska A., Zarządzanie projektami unijnymi. Teoria i praktyka, Difin, str.180]. Respondenci biorący udział w wywiadach wskazali trzy obszary w ramach których wykrywanych jest najwięcej nieprawidłowości. Są to: proces wyboru dostawców/wykonawców, proces dokonywania zakupów projektowych oraz proces regulowania płatności za nabywane towary, usługi i roboty budowlane.

Podsumowanie wyników przeprowadzonych wywiadów IDI przedstawia tabela $\mathrm{nr} 2$.

Tabela nr 2. Nieprawidłowości wykrywane w trakcie weryfikacji wniosków o płatność w ramach PO IG

\begin{tabular}{|c|c|}
\hline Obszar realizacji projektu & Wykrywane nieprawidłowości \\
\hline $\begin{array}{c}\text { Proces wyboru dostawców/ } \\
\text { wykonawców }\end{array}$ & $\begin{array}{l}\text { - wybór dostawcy/wykonawcy bez przeprowadzenia postępowania ofer- } \\
\text { towego/przetargu, } \\
\text { - uchybienia w procesie wyboru dostawców/wykonawców, } \\
\text { - powiązania osobowe lub kapitałowe pomiędzy beneficjentem } \\
\text { a dostawca/wykonawca. }\end{array}$ \\
\hline $\begin{array}{c}\text { Proces zakupu towarów/ } \\
\text { usług/ robót }\end{array}$ & $\begin{array}{l}\text { - dokonywanie zakupów niezgodnych z kategoriami wydatków } \\
\text { z harmonogramu rzeczowo-finansowego projektu, } \\
\text { - dokonywanie zakupów niespełniających kryterium niezbędności } \\
\text { do osiagnięcia celu projektu/racjonalności/gospodarności, } \\
\text { - dokonywanie zakupów przekraczających limity kwotowe/procentowe } \\
\text { określone dla danej kategorii wydatku. }\end{array}$ \\
\hline $\begin{array}{l}\text { Proces dokonywanie płat- } \\
\text { ności }\end{array}$ & $\begin{array}{l}\text { - dokonywanie płatności gotówkowych za towary/usługi/roboty nabywa- } \\
\text { ne w ramach projektu, } \\
\text { - ponoszenie wydatków po okresie kwalifikowalności. }\end{array}$ \\
\hline
\end{tabular}

Źródło: Opracowanie własne na podstawie przeprowadzonych wywiadów.

Najwięcej nieprawidłowości popełniają beneficjenci w trakcie proces wyboru kontrahentów (naruszając zasadę konkurencyjności lub Prawo zamówień publicznych). Wykrycie nieprawidłowości w omawianym obszarze możliwe jest dzięki załączaniu do wniosków o płatność dokumentów potwierdzających przeprowadzoną procedurę przetargową. Najczęściej występujące nieprawidłowości dotyczą:

- wyboru dostawcy/wykonawcy bez przeprowadzenia postępowania ofertowego/przetargu bądź w oparciu o tryb niezgodny $\mathrm{z}$ zapisami umowy o dofinansowanie (przeprowadzenie rozeznania rynku zamiast zapytania ofertowego) lub Prawem zamówień publicznych (tryb zamówienia z wolnej ręki zamiast przetargu nieograniczonego),

- uchybień w procesie wyboru dostawców/wykonawców w tym: nieupublicznienia zapytania ofertowego na stronie internetowej, wskazania w zapytaniu ofertowym/SIWZ niepełnego (nieprawidłowego) opisu 
przedmiotu zamówienia, skonstruowania opisu przedmiotu zamówienia w sposób naruszający zasadę uczciwej konkurencji (np.: poprzez odniesienie się do znaków towarowych bez dopuszczenia możliwości składania ofert z rozwiązaniami równoważnymi), braku potwierdzenia wysłania zapytania ofertowego do 3 potencjalnych oferentów,

- występowania powiązań osobowych lub kapitałowych pomiędzy beneficjentem a kontrahentem. Nieprawidłowości wykrywane są najczęściej $\mathrm{w}$ toku weryfikacji danych rejestrowych beneficjenta (CEiDG, KRS) lub $\mathrm{w}$ procesie weryfikacji powiązań za pośrednictwem baz danych on-line (np.: baza Polskiej Wywiadowni Gospodarczej).

Kolejnym obszarem w ramach którego wykrywane są nieprawidłowości, $\mathrm{w}$ toku weryfikacji sprawozdań $\mathrm{z}$ realizacji projektów, jest proces zakupów towarów, usług i robót budowlanych. Do najczęstszych przyczyn niekwalifikowalności wydatków ponoszonych przez beneficjentów w analizowanym obszarze respondenci zaliczyli:

- dokonywanie zakupów niezgodnych $\mathrm{z}$ kategoriami wydatków $\mathrm{z}$ harmonogramu rzeczowo-finansowego (np.: rozszerzenie zakresu zaplanowanych do realizacji zadań poprzez zakup dodatkowego wyposażenia środka trwałego niewskazanego we wniosku aplikacyjnym),

- dokonywanie zakupów niespełniających kryteriów niezbędności do osiągnięcia celu projektu, nieracjonalnych lub świadczących o niegospodarności np.: zakup ekspertyzy o niskiej wartości merytorycznej, nabycie nieruchomości po cenie wyższej niż wartość rynkowa wskazana w operacie szacunkowym ${ }^{10}$,

- dokonywanie zakupów przekraczających limity kwotowe/procentowe określone dla danej kategorii wydatku np.: przekroczenie limitu kwotowego na noclegi w przypadku uczestnictwa przedstawicieli beneficjenta w misjach/targach zagranicznych ${ }^{11}$ lub limitu kwalifikowania kosztów zakupu gruntu/prawa wieczystego użytkowania gruntu (maksymalnie 10\% całkowitych wydatków kwalifikowalnych).

Ostatnim obszarem występowania nieprawidłowości wskazanym przez respondentów w przeprowadzonych wywiadach jest proces dokonywania płatności. Wykrywane uchybienia związane są z dokonywaniem zapłaty gotówkowej za nabywane towaru, usługi lub roboty budowlane (pomimo wskazanego $\mathrm{w}$ umowie o dofinansowanie obowiązku regulowania wszelkich płatności za po-

\footnotetext{
${ }^{10}$ sporządzonym przez niezależnego rzeczoznawcę majątkowego.

${ }^{11}$ limity kwotowe określa Rozporządzenie Ministra pracy i polityki społecznej z 29 stycznia 2013 r. $\mathrm{w}$ sprawie należności przysługujących pracownikowi zatrudnionemu w państwowej lub samorządowej jednostce sfery budżetowej z tytułu podróży służbowej
} 
średnictwem rachunku bankowego ${ }^{12}$ ) lub ponoszeniem wydatków po okresie kwalifikowalności tj.: po dniu zakończenia okresu realizacji projektu, wskazanego w umowie o dofinansowanie.

Podsumowując przeprowadzone badanie, można stwierdzić, że ocena wniosku beneficjenta o płatność pozwala na monitorowanie prawidłowości realizacji zadań projektowych począwszy od procesu wyboru dostawcy/wykonawcy, poprzez proces zakupów projektowych, rejestracji zdarzeń gospodarczych w ewidencji księgowej beneficjenta, aż po proces regulowania płatności. Choć dane dostarczane w ramach systemu sprawozdawczego są cennym źródłem informacji wykorzystywanych do zarządzania programami operacyjnymi należy pamiętać, że proces monitoringu projektu, przeprowadzany wyłącznie w oparciu o składane sprawozdania, uniemożliwia potwierdzenie faktycznej realizacji działań projektowych (np.: posiadania i wykorzystywania na cele realizacji projektu środka trwałego wskazanego na fakturze załączonej do wniosku o płatność). Powyższe możliwe jest wyłącznie w trakcie kontroli na miejscu realizacji projektu ${ }^{13}$.

\section{PODSUMOWANIE}

Obowiązek sprawozdawczy nałożony na beneficjentów korzystających ze wsparcia finansowego Unii Europejskiej, realizowany w postaci cyklicznie składanych wniosków o płatność, dostarcza instytucjom zaangażowanych we wdrażanie funduszy unijnych danych rzeczowych i finansowych niezbędnych do zarządzania programem operacyjnym zarówno na poziomie operacyjnym jak i strategicznym. Rzetelne i wiarygodne dane dotyczące realizowanych projektów, przekazywane przez biorców pomocy wspólnotowej, stanowią podstawowe źródło wiedzy o realizacji programu operacyjnego, Narodowych Strategicznych Ram Odniesienia oraz polityki spójności.

Przeprowadzone badanie jakościowe wykazało, że wdrożony w ramach perspektywy finansowej 2007-2013 system sprawozdawczości projektów okazał się skutecznym narzędziem wykrywania nieprawidłowości. Jego rola w systemie ochrony interesów finansowych Unii

${ }^{12}$ do czasu wprowadzenia powyższego zapisu w umowach o dofinansowanie w ramach POIG beneficjenci mieli możliwość dokonywania płatności gotówkowych pod warunkiem spełnienia przesłanki wskazanej w art. 22 Ustawy o swobodzie działalności gospodarczej. Zgodnie z w/w artykułu transakcje realizowane przez przedsiębiorców o wartości przekraczającej równowartość 15 tys. EUR powinny być dokonywane za pośrednictwem systemu bankowego. Konsekwencją dokonania zapłaty gotówkowej w przypadku przekroczenia ww. limitu kwotowego było uznanie na etapie oceny wniosku o płatność wydatku za niekwalifikowany (w związku z naruszeniem przepisów prawa krajowego).

${ }^{13} \mathrm{w}$ trakcie wywiadów wskazano dwa przypadki w których w trakcie kontroli na miejscu wykryto, że beneficjent nie dokonał zakupów środków trwałych. Załączone do wniosku o płatność dokumenty potwierdzające zakup i przyjęcie do użytkowania środków trwałych nie były zgodne ze stanem faktycznym. 
Europejskiej i budżetu państwa jest bardzo istotna ponieważ umożliwia wykrycie uchybień często przed dokonaniem płatności na rzecz beneficjenta.

Pozostaje mieć nadzieję, że uproszczenia wprowadzane w ramach programów operacyjnych perspektywy finansowej 2014-2020 w obszarze rozliczeń projektów m.in.: uproszczone metody rozliczania (stawki jednostkowe i kwoty ryczałtowe), weryfikacja wniosków o płatność w oparciu o próbę dokumentów oraz elektroniczny system obiegu dokumentów SL2014 przyczynią się do sprawniejszej realizacji przedsięwzięć unijnych bez szkody dla jakości i skuteczności procesów zarządczych w obszarze monitorowania postępów wdrażania projektów finansowanych ze środków Europejskich Funduszy Strukturalnych i Inwestycyjnych.

\title{
LITERATURA
}

Centrum Obsługi Przedsiębiorcy (2011), Instrukcji wypetniania wniosku beneficjenta o platność w ramach RPO WE na lata 2007-2013, III oś priorytetowa Gospodarka, Innowacyjność, Przedsiębiorczość:http://www.20072013.cop.lodzkie.pl/index.php/component/content/article/227.html\#zalaczniki_do_wniosku_o_platnosc [04.02.2017].

Domiter M., Marciszewska A., (2013), Zarzadzanie projektami unijnymi. Teoria i praktyka, Difin S.A., Warszawa.

Grucza B., Trocki M., (2007), Zarzadzanie projektem europejskim, Polskie Wydawnictwo Ekonomiczne, Warszawa.

Piątkowska K., Wielguszewska K., (2008), Zasady sprawozdawczości w projektach wspólfinansowanych $w$ ramach polityki spójności UE, [w:] Praca zbiorowa: Zarządzanie, sprawozdawczość, kontrola, promocja i ewaluacja projektów dofinansowanych z funduszy unijnych, Twigger, Warszawa.

Ministerstwo Rozwoju, (2016), Wytyczne w zakresie sprawozdawczości. Narodowe Strategiczne Ramy Odniesienia,

Polska Agencja Rozwoju Przedsiębiorczości (2013), Zasady sporządzania wniosku beneficjenta o płatność: https://poig.parp.gov.pl/files/74/108/204/18223.pdf [02.04.2017]

\section{BENEFICIARY PAYMENT APPLICATION AS A TOOL FOR MONITORING EUROPEAN UNION PROJECTS}

\begin{abstract}
The article presents a payment application prepared by a beneficiary as an instrument of monitoring the compliance of the project implementation with the polish and European Union law, financing agreement and funding application. This work contains the general characteristics of project monitoring system of EU funds in Poland, the description of payment application as well as characteristics of beneficiaries reporting obligations. The article also presents the results of studies conducted with representatives of institutions involved in the implementation of Operational Programme Innovative Economy engaged in process of verification of payment applications and the significant role the application for payments in management of the european funds. The interviews have identified the most frequently detected irregularities in the process of verifying the applications for payment.
\end{abstract}

Keywords: application for payment, european funds 